\title{
Exogenous surfactant improves survival and surfactant function in ischaemia-reperfusion injury in minipigs
}

\author{
J.M. Hohlfeld ${ }^{+}$, M. Strüber*, K. Ahlf ${ }^{+}$, M.M. Hoeper ${ }^{+}$, S. Fraund*, N. Krug ${ }^{+}$, G. Warnecke*, \\ W. Harringer*, A. Haverich*, H. Fabel ${ }^{+}$
}

Exogenous surfactant improves survival and surfactant function in ischaemia-reperfusion injury in minipigs. J.M. Hohlfeld, M. Strüber, K. Ahlf, M.M. Hoeper, S. Fraund, N. Krug, G. Warnecke, W. Harringer, A. Haverich, H. Fabel. (C) ERS Journals Ltd 1999.

ABSTRACT: Reperfusion injury is the major cause of early morbidity and mortality after lung transplantation. This complication has been experimentally linked to dysfunction of pulmonary surfactant. Therefore, the hypothesis that reperfusion injury might be preventable by exogenous surfactant treatment was tested.

Left lungs of minipigs were exposed to $120 \mathrm{~min}$ of ischaemia, and the lungs were then reperfused for up to $7 \mathrm{~h}$. Animals were divided into a control group and a surfactant group $\left(n=5\right.$ each). The surfactant group received $50 \mathrm{mg} \cdot \mathrm{kg}^{-1}$ Alveofact $\AA$ intrabronchially via a bronchoscope at the beginning of the ischaemic period. Bronchoalveolar lavage was performed at baseline before ischaemia and $90 \mathrm{~min}$ after reperfusion.

Surfactant treatment significantly improved short-term survival. Pulmonary vascular resistance increased markedly in control animals leading to right heart failure and death within $3 \mathrm{~h}$ after reperfusion whereas the surfactant-treated animals survived the $7 \mathrm{~h}$ observation period. After reperfusion, alveolar accumulation of neutrophils and exuded proteins was present in both groups to the same extent. Surfactant activity after reperfusion deteriorated markedly in the control group but was preserved in the surfactant group.

In conclusion, early surfactant treatment alleviates the deterioration of surfactant function and improves survival in this minipig model of ischaemia-reperfusion injury. Eur Respir J 1999; 13: 1037-1043.

Ischaemia-reperfusion injury has a major impact on morbidity and mortality in the early postoperative course after lung transplantation [1], and it is a feared complication following pulmonary thromboendarterectomy [2]. Several mechanisms are involved in ischaemia-reperfusion injury including activation of leukocytes, platelets and complement, as well as release of oxygen free radicals and other inflammatory mediators [3]. Recent research has highlighted the possibility that surfactant alterations contribute to ischaemia-reperfusion injury [47]. Surfactant is composed of a complex mixture of mainly phospholipids and surfactant-associated proteins [8]. Surfactant reduces the surface tension at the airliquid interface of the lungs, thereby preventing alveolar collapse and airway closure at end expiration. Moreover, its high surface pressure prevents alveolar oedema. Surfactant dysfunction occurs through a wide variety of mechanisms which include inhibition by exuded plasma proteins [9-11], dilution from alveolar oedema [12, 13], enzymatic cleavage of surfactant components [14-16] and type II cell injury. In reperfusion injury, it has been suggested that surfactant dysfunction occurred due to inhibition by exuded plasma proteins and that dysfunctioning surfactant promotes alveolar oedema, thus leading to a vicious circle.
The degree of surfactant dysfunction in reperfusion injury is similar to the impairment of surfactant found in acute respiratory distress syndrome (ARDS) $[17,18]$. The first clinical trials have evaluated the use of exogenous surfactant in the management of patients with ARDS with encouraging results $[19,20]$. The possible role of surfactant replacement therapy in reperfusion injury was also addressed in studies of experimental lung transplantation [21-24] and for the management of lung transplant recipients with severe reperfusion injury [25].

To further study the efficacy of exogenously administered surfactant in reperfusion injury, a minipig model of ischaemia-reperfusion injury was designed and the effect of surfactant application on the severity of reperfusion damage, surfactant function, and survival studied.

\section{Materials and methods}

\section{Animals}

Ten female minipigs (Ellegaard, Dalmose, Denmark) weighing $30-35 \mathrm{~kg}$ were used in this study. Animals received humane care in strict compliance with the "Principles of Laboratory Animal Care" formulated by the 
National Society for Medical Research and the "Guide for the Care and Use of Laboratory Animals" [26]. The study was approved by the State Ethics Committee of Lower Saxony, Germany.

\section{Experimental procedure}

Respiratory mechanics. The animals were orotracheally intubated ( $7.5 \mathrm{~mm}$ tube) after initial bolus injection of $0.2 \mathrm{mg}$ fentanyl and $0.25 \mathrm{~g}$ thiopental. General anaesthesia was maintained by infusion of fentanyl $\left(0.1 \mu \mathrm{g} \cdot \mathrm{kg}^{-1}\right.$. $\left.\mathrm{min}^{-1}\right)$ and thiopental $\left(80 \mu \mathrm{g} \cdot \mathrm{kg}^{-1} \cdot \mathrm{min}^{-1}\right)$, together with pancuronium $\left(2 \mathrm{mg} \cdot \mathrm{h}^{-1}\right)$ for relaxation. The minipigs were mechanically ventilated in a pressure-limited mode (tidal volume $(V \mathrm{~T}) 12 \mathrm{~mL} \cdot \mathrm{kg}^{-1}$, breathing frequency 15 breaths $\cdot \min ^{-1}$, maximum inspiratory pressure $30 \mathrm{hPa}$, positive end-expiratory pressure (PEEP) $5 \mathrm{hPa}$, inspiratory expiratory ratio (I:E) 1:1) with an EVITA-2-respirator (Dräger Werke, Lübeck, Germany) at a constant inspiratory oxygen fraction $\left(F \mathrm{I}, \mathrm{O}_{2}\right)$ of 0.5 throughout the experiment. Parameters of mechanical ventilation (minute volume $\left(V^{\prime} \mathrm{E}\right)$, expiratory tidal volume $(V \mathrm{~T}, \mathrm{e})$, plateau pressure $(P$ plat $)$ and respirator compliance $(C))$ were documented at baseline (see below) and every $30 \mathrm{~min}$ during reperfusion.

Haemodynamics. Following thoracotomy, a $7 \mathrm{~F}$ flowdirected, balloon-tipped Swan-Ganz-catheter (No. 131F7; Baxter, Irvine, CA, USA) was placed into the main stem of the pulmonary artery under manual guidance. In addition, left atrial and arterial catheters were placed (18 G LeatherCath; Vygon, Aachen, Germany). After stabilization for $10 \mathrm{~min}$, baseline haemodynamics, blood gases, and ventilator variables were obtained. The cardiac output was measured by the thermodilution technique and calculated using an analogue computer system (Cardiac output computer COM-2; Baxter). Pulmonary vascular resistance (PVR) was computed using the standard equation. The alveolar-arterial oxygen pressure difference $\left(P \mathrm{~A}-\mathrm{a}, \mathrm{O}_{2}\right)$ was computed according to the following standard simplified equation: $P \mathrm{~A}-\mathrm{a}, \mathrm{O}_{2}=$ alveolar oxygen tension $\left(P \mathrm{~A}, \mathrm{O}_{2}\right)$ - arterial oxygen tension $\left(\mathrm{Pa}, \mathrm{O}_{2}\right)$, where $P \mathrm{~A}, \mathrm{O}_{2}=F \mathrm{I}, \mathrm{O}_{2}$ (barometric pressure - 47) - arterial carbon dioxide tension $\left(\mathrm{Pa}_{\mathrm{a}}, \mathrm{CO}_{2}\right)$ /respiratory quotient $(R)$. In the latter equation, 47 is the airway water vapour pressure at $37^{\circ} \mathrm{C}$ in torr, and $R$ is assumed to be 0.8 . Haemodynamic variables were determined at baseline and every 30 min during reperfusion.

Lung preservation and reperfusion. After baseline haemodynamic monitoring, the left lung was prepared for flush preservation. Heparin (200 immunizing units (IE). $\mathrm{kg}^{-1}$ ) was given $30 \mathrm{~min}$ before lung perfusion with preservation solution. The left pulmonary artery and left pulmonary veins were clamped, while ventilation of both lungs was continued. A catheter was placed into the left pulmonary artery. The pulmonary veins were incised and the left lung was selectively perfused for 15 min with $1 \mathrm{~L}$ of Euro-Collins solution at $4^{\circ} \mathrm{C}$ via the pulmonary artery catheter [27]. At the end of flush preservation, the veins were sutured. After $2 \mathrm{~h}$ of ischaemia, the lung was reperfused by first opening the venous clamp followed by the arterial clamp (time after reperfusion $=0 \mathrm{~min}$ ). The circulation was allowed to stabilize for $15 \mathrm{~min}$ before the contralateral right pulmonary artery and bronchus were clamped. The thorax remained open throughout the experiment. To prevent early right heart failure, adrenalin was started after reperfusion at $0.1 \mu \mathrm{g} \cdot \mathrm{kg}^{-1} \cdot \mathrm{min}^{-1}$ to maintain cardiac output and systemic arterial pressure. Whenever cardiac output fell below $2.5 \mathrm{~L} \cdot \mathrm{min}^{-1}$ or mean systemic arterial pressure was below $8.0 \mathrm{kPa}(60 \mathrm{mmHg})$, the adrenalin dose was increased by $0.2 \mu \mathrm{g} \cdot \mathrm{kg}^{-1} \cdot \mathrm{min}^{-1}$ up to a maximum dose of $3 \mu \mathrm{g} \cdot \mathrm{kg}^{-1} \cdot \mathrm{min}^{-1}$. The experiment was terminated $7 \mathrm{~h}$ after reperfusion.

\section{Surfactant treatment}

Animals were alternately assigned to either an untreated control group $(n=5)$ or treated intrabronchially with exogenous surfactant $\left(50 \mathrm{mg} \cdot \mathrm{kg}^{-1}\right.$ Alveofact $\mathrm{R}$; provided by K. Thomae, Biberach, Germany) $(n=5)$. In this study, Alveofact $\mathbb{R}$ was choosen for surfactant supplementation because it has been shown that this bovine lipid extract surfactant has a good efficacy to resist protein inhibition [11]. Surfactant was segmentally instilled into the left lung by bronchoscopy at the beginning of the 120-min ischaemic period. Starting in the lower lobe, the bronchoscope was placed into a segment in a wedge position and an aliquot of surfactant $(\sim 4 \mathrm{~mL})$ was gently instilled, followed by $5 \mathrm{~mL}$ of air. After $\sim 1 \mathrm{~min}$ the bronchoscope was slowly drawn back and the procedure was continued in a neighbouring segment. The instillation procedure took $\sim 15 \mathrm{~min}$. Sham bronchoscopies with saline instillation were not carried out in the control group because of presumed negative effects on alveolar surfactant balance.

\section{Bronchoalveolar lavage}

Two bronchoalveolar lavage (BAL) procedures were performed in all animals. The initial BAL was performed in the right middle lobe at baseline. A second BAL was obtained from the lingula of the left lung $90 \mathrm{~min}$ after reperfusion. Briefly, a fibreoptic bronchoscope (Olympus P10, Tokyo, Japan) was wedged into the appropriate bronchus and the lavage carried out with warm saline solution in five aliquots of $20 \mathrm{~mL}$. Following instillation, each aliquot was aspirated with gentle suction. The BAL fluid (BALF) was pooled and the recovered volume recorded ("recovery"). The fluid was filtered through sterile gauze and then centrifuged at $250 \times g$ for 10 min to obtain a cell free supernatant, which was stored at $-28^{\circ} \mathrm{C}$ until further analysis. From the cell pellet the total number of cells in the BALF was counted and a differential cell count was performed using standard techniques.

\section{Protein and phospholipid analysis}

Aliquots of the cell free supernatant were used for determination of protein concentrations according to LOWRY et al. [28] and of phospholipid concentrations according to the method of BARTLETT [29]. The latter assay is based on a phosphorus determination carried out on the lipids extracted with chloroform/methanol according to BLIGH and DYER [30]. All assays were performed in duplicate and the mean value was reported. 


\section{Surfactant isolation and aggregate separation}

The cell-free supernatant was centrifuged at $48,000 \times g$ for $60 \mathrm{~min}$ at $4^{\circ} \mathrm{C}$ to pellet large surfactant aggregates (LA). The supernatant, containing small surfactant aggregates (SA), was removed and the LA pellet was resuspended in Ringer's solution. The phospholipid contents of the LA pellets and the SA supernatants were determined as described above. By adding Ringer's solution, the phospholipid concentration of the LA suspension was adjusted to $1 \mathrm{mg} \cdot \mathrm{mL}^{-1}$ for studying surface properties with the pulsating bubble surfactometer (Electronetics, Buffalo, NY, USA).

\section{Surface activity evaluated with the pulsating bubble sur- factometer}

Surface activity of BALF was measured with a pulsating bubble surfactometer [31]. Briefly, $40 \mu \mathrm{L}$ of the LA suspension, which had been adjusted to a phospholipid concentration of $1 \mathrm{mg} \cdot \mathrm{mL}^{-1}$, was used for filling the sample chamber with a micropipette. The surface tension used for statistical analysis of this study was the value at minimal bubble size $(\gamma \mathrm{min})$, registered after $5 \mathrm{~min}$ of bubble pulsation at a rate of 20 cycles $\cdot \mathrm{min}^{-1}$ and at a temperature of $37^{\circ} \mathrm{C}$. Before starting bubble pulsation, the initial surface tension $(\gamma 0)$ after bubble formation was measured and the adsorption rate ( $\gamma$ ads) was evaluated by determining surface tension $10 \mathrm{~s}$ after formation of a bubble. All analogue data were digitalized and recorded by computer.

\section{Statistics}

Results are expressed as mean \pm SEM. Unless otherwise stated, the parameters after reperfusion were analysed at $120 \mathrm{~min}$ and at the individual end-points which were shortly before death or sacrifice. Within treatment groups the differences before and after reperfusion were tested by Wilcoxon's rank-sum test. Differences between the study groups (control versus surfactant) were tested by the Mann-Whitney U-test [32]. A p-value of $<0.05$ was considered significant.

\section{Results}

Survival, haemodynamics, respiratory mechanics, and oxygenation

Following reperfusion, all control animals developed a rapidly progressive increase of PVR that uniformely resulted in fatal right heart failure after $186 \pm 26 \mathrm{~min}$. In contrast, surfactant-treated animals exhibited a less severe increase in PVR and all except one survived until sacrifice (table 1).

In control animals, cardiac output decreased from $2.68 \pm$ $0.17 \mathrm{~L} \cdot \mathrm{min}^{-1}$ at baseline to $1.60 \pm 0.36 \mathrm{~L} \cdot \mathrm{min}^{-1}$ after 120 min of reperfusion and went down further to $0.74 \pm 0.28$ $\mathrm{L} \cdot \mathrm{min}^{-1}$ shortly before death. In contrast, cardiac output decreased significantly less in the surfactant group (2.92 \pm $0.12 \mathrm{~L} \cdot \mathrm{min}^{-1}$ at baseline, $2.46 \pm 0.22 \mathrm{~L} \cdot \mathrm{min}^{-1}$ after $120 \mathrm{~min}$ of reperfusion and $1.78 \pm 0.18 \mathrm{~L} \cdot \mathrm{min}^{-1}$ shortly before death/ sacrifice; table 1). In addition, control animals required
Table 1. - Survival, haemodynamic and oxygenation data

\begin{tabular}{|c|c|c|c|}
\hline & Control & Surfactant & $\mathrm{p}$-value \\
\hline Survival min & $186 \pm 26$ & $408 \pm 12$ & 0.009 \\
\hline \multicolumn{4}{|l|}{$\mathrm{CO} \mathrm{L} \cdot \mathrm{min}^{-1}$} \\
\hline Baseline & $2.68 \pm 0.17$ & $2.92 \pm 0.12$ & 0.30 \\
\hline After $120 \mathrm{~min}$ & $1.60 \pm 0.36$ & $2.46 \pm 0.22$ & 0.10 \\
\hline At death/sacrifice & $0.74 \pm 0.28$ & $1.78 \pm 0.18$ & 0.02 \\
\hline \multicolumn{4}{|l|}{ PVR dynes $\cdot \mathrm{cm} \cdot \mathrm{s}^{-5}$} \\
\hline Baseline & $321 \pm 94$ & $429 \pm 86$ & 0.35 \\
\hline After $120 \mathrm{~min}$ & $1889 \pm 813$ & $1014 \pm 223$ & 0.47 \\
\hline At death/sacrifice & $3307 \pm 1041$ & $1482 \pm 178$ & 0.18 \\
\hline \multicolumn{4}{|l|}{ PAP $\mathrm{mmHg}$} \\
\hline Baseline & $16 \pm 3$ & $18 \pm 3$ & 0.75 \\
\hline After $120 \mathrm{~min}$ & $33 \pm 6$ & $38 \pm 7$ & 0.47 \\
\hline At death/sacrifice & $28 \pm 4$ & $37 \pm 7$ & 0.25 \\
\hline \multicolumn{4}{|l|}{ SAP mmHg } \\
\hline Baseline & $66 \pm 2$ & $75 \pm 5$ & 0.18 \\
\hline After $120 \mathrm{~min}$ & $44 \pm 10$ & $71 \pm 7$ & 0.08 \\
\hline At death/sacrifice & $21 \pm 4$ & $56 \pm 7$ & 0.009 \\
\hline \multicolumn{4}{|l|}{ LAP mmHg } \\
\hline Baseline & $6 \pm 1$ & $7 \pm 1$ & 0.60 \\
\hline After $120 \mathrm{~min}$ & $6 \pm 2$ & $6 \pm 2$ & 0.92 \\
\hline At death/sacrifice & $6 \pm 2$ & $4 \pm 1$ & 0.53 \\
\hline \multicolumn{4}{|l|}{$\mathrm{Pa}_{\mathrm{a}, \mathrm{O}_{2}} \mathrm{mmHg}$} \\
\hline Baseline & $231 \pm 24$ & $271 \pm 32$ & 0.08 \\
\hline After $120 \mathrm{~min}$ & $127 \pm 53$ & $157 \pm 28$ & 0.25 \\
\hline At death/sacrifice & $50 \pm 12$ & $56 \pm 4$ & 0.46 \\
\hline \multicolumn{4}{|l|}{$\mathrm{Pa}_{\mathrm{a}, \mathrm{CO}_{2} \mathrm{mmHg}}$} \\
\hline Baseline & $44 \pm 2$ & $37 \pm 4$ & 0.10 \\
\hline After $120 \mathrm{~min}$ & $53 \pm 7$ & $45 \pm 5$ & 0.75 \\
\hline At death/sacrifice & $62 \pm 13$ & $59 \pm 11$ & 0.81 \\
\hline \multicolumn{4}{|l|}{$P \mathrm{~A}-\mathrm{a}, \mathrm{O}_{2} \mathrm{mmHg}$} \\
\hline Baseline & $91 \pm 23$ & $56 \pm 31$ & 0.08 \\
\hline After $120 \mathrm{~min}$ & $187 \pm 48$ & $164 \pm 29$ & 0.35 \\
\hline At death/sacrifice & $257 \pm 10$ & $253 \pm 8$ & 0.81 \\
\hline \multicolumn{4}{|l|}{ HR beats. $\min ^{-1}$} \\
\hline Baseline & $74 \pm 12$ & $85 \pm 8$ & 0.35 \\
\hline After $120 \mathrm{~min}$ & $110 \pm 17$ & $97 \pm 5$ & 0.99 \\
\hline At death/sacrifice & $110 \pm 25$ & $108 \pm 5$ & 0.60 \\
\hline \multicolumn{4}{|c|}{ Adrenalin $\mu \mathrm{g} \cdot \mathrm{min}^{-1} \cdot \mathrm{kg}^{-1}$} \\
\hline Baseline & 0 & 0 & \\
\hline After $120 \mathrm{~min}$ & $1.50 \pm 0.52$ & $0.26 \pm 0.01$ & 0.04 \\
\hline At death/sacrifice & $1.56 \pm 0.51$ & $0.31 \pm 0.02$ & 0.04 \\
\hline
\end{tabular}

CO: cardiac output; PVR: pulmonary vascular resistance; PAP: mean pulmonary artery pressure; SAP: mean systemic arterial pressure; LAP: mean left arterial pressure; $\mathrm{Pa}_{\mathrm{a}} \mathrm{O}_{2}$ : arterial oxygen tension; $\mathrm{Pa}_{\mathrm{a}} \mathrm{CO}_{2}$ : arterial carbon dioxide tension; $\mathrm{PA}-\mathrm{a}, \mathrm{O}_{2}$ : alveolar-arterial oxygen pressure difference; HR: heart rate. Data are reported before left lungs were made ischaemic (baseline), after $120 \mathrm{~min}$ of reperfusion and shortly before death or sacrifice (at death/sacrifice). Values are given as mean \pm SEM. $(1 \mathrm{mmHg}=$ $0.133 \mathrm{kPa}$.)

much higher doses of adrenalin to maintain cardiac output and systemic arterial blood pressure compared to surfactant-treated animals (table 1). Left atrial pressures remained normal in both groups throughout the entire experiment (table 1).

At baseline, $P \mathrm{a}, \mathrm{O}_{2}$ and $\mathrm{PA}-\mathrm{a}, \mathrm{O}_{2}$ values were similar in the control and in the surfactant group. Moreover, oxygenation variables were not different in the two groups during the initial $2 \mathrm{~h}$ of reperfusion or shortly before death or sacrifice (table 1). In contrast, $V^{\prime}$ E markedly decreased and compliance deteriorated during reperfusion in untreated control animals, whereas surfactant treatment alleviated the loss of compliance and prevented deterioration of $V^{\prime} \mathrm{E}$ (fig. 1). 

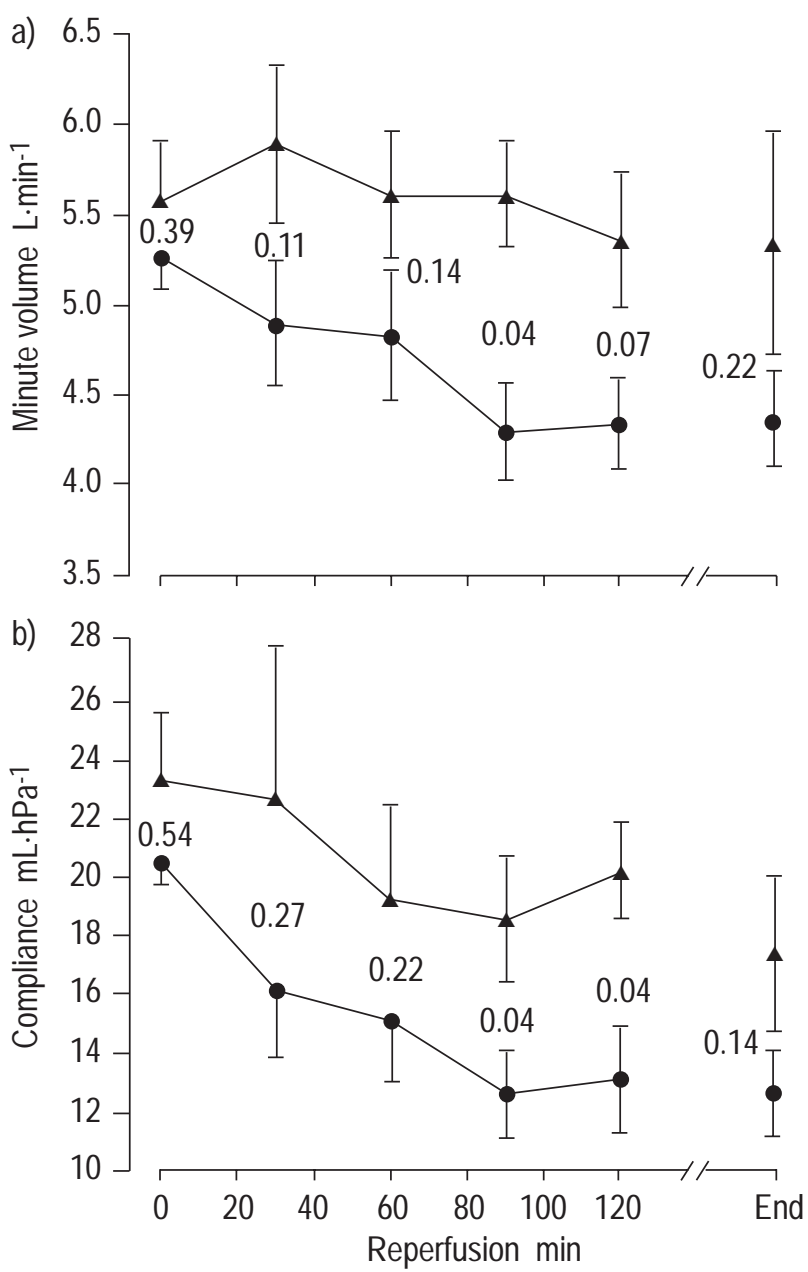

Fig. 1. - Minute volume (a) and respirator compliance (b) during the $120 \mathrm{~min}$ of reperfusion and shortly before death or sacrifice (End) in untreated control animals $(\bullet)$ and in surfactant-treated animals $(\boldsymbol{\Delta})$. Values are given as mean \pm SEM and exact $p$-values are shown.

\section{Cells in bronchoalveolar lavage fluid}

The total cell numbers recovered from BALF at baseline did not differ between the control and the surfactant-treated group (table 2). After reperfusion, there was a slight but nonsignificant increase of total cells in both groups which was more pronounced in the surfactant group.

Analysis of differential cell counts showed a similar distribution in the control and in the surfactant group at baseline with $\sim 90 \%$ macrophages as the predominant cells. After reperfusion, there was a marked increase in neutro- phils ( $>50 \%$ ), accompanied by a decrease in macrophages, and a slight increase in lymphocytes in both groups without a difference between control and surfactant-treated animals (table 2).

Phospholipids and proteins in bronchoalveolar lavage fluid

Phospholipid concentrations in BALF from both groups were not different at baseline. In the control group, the phospholipid concentration remained unchanged after reperfusion compared to baseline. Exogenous surfactant treatment increased the phospholipid concentration comared to pretreatment values ( $\mathrm{p}=0.04$, fig. $2 \mathrm{a}$ ). The difference between the control and surfactant group was close to statistical significance $(\mathrm{p}=0.08)$.

Proteins in the BALF at baseline were low in both groups but increased 15-20-fold after reperfusion without a difference between the two groups (fig. 2b). High-speed centrifugation co-pelleted proteins leading to protein concentrations in the LA pellet of $790 \pm 292 \mu \mathrm{g} \cdot \mathrm{mL}^{-1}$ and $757 \pm 178 \mu \mathrm{g} \cdot \mathrm{mL}^{-1}$ in control and surfactant-treated animals, respectively. At baseline, the ratio of protein to phospholipid as a marker of the inhibitory potential on surfactant function was not different between the control and the surfactant group. Reperfusion resulted in a marked increase in the protein to phospholipid ratio in control animals whereas the treatment with exogenous surfactant alleviated this increase (fig. 3a).

The ratio of SA:LA was determined as an indicator for metabolic conversion of the surfactant material. As seen in figure $3 \mathrm{~b}$, the SA:LA was low under baseline conditions in both groups and increased dramatically after reperfusion in the control group $(\mathrm{p}=0.04)$, but was unchanged in lavage from surfactant-treated animals $(\mathrm{p}=$ $0.50)$.

Surface activity evaluated with the pulsated bubble surfactometer

The adsorption rate $\gamma$ ads, defined as the surface tension of the uncycled bubble $10 \mathrm{~s}$ after bubble formation, was $\sim 28 \mathrm{mN} \cdot \mathrm{m}^{-1}$ in both study groups at baseline (fig. $4 \mathrm{a}$ ). In the control group, the $\gamma$ ads showed higher values after reperfusion $(\mathrm{p}=0.14)$, whereas in the surfactant group there was a slight decrease of the adsorption rate values $(p=0.69)$. After reperfusion the difference in $\gamma$ ads was significant between the control and the surfactant group $(\mathrm{p}=0.02)$.

Surface tension at minimal bubble size after five minutes of pulsation $\left(\gamma \mathrm{min}\right.$ ) was $\sim 2 \mathrm{mN} \cdot \mathrm{m}^{-1}$ in both groups at

Table 2. - Cellular analysis of bronchoalveolar lavage

\begin{tabular}{|c|c|c|c|c|c|c|c|}
\hline & \multicolumn{3}{|c|}{ Control } & \multicolumn{3}{|c|}{ Surfactant } & \multirow[b]{2}{*}{ p-value ${ }^{+}$} \\
\hline & Baseline & Reperfusion & p-value* & Baseline & Reperfusion & p-value* & \\
\hline Total cells $\mu \mathrm{L}^{-1}$ & $136 \pm 19$ & $173 \pm 87$ & 0.99 & $156 \pm 45$ & $293 \pm 150$ & 0.35 & 0.33 \\
\hline Macrophages \% & $95 \pm 2$ & $48 \pm 22$ & 0.11 & $91 \pm 2$ & $37 \pm 13$ & 0.07 & 0.72 \\
\hline Lymphocytes \% & $4 \pm 2.1$ & $16 \pm 11$ & 0.29 & $5 \pm 1.4$ & $10 \pm 4.5$ & 0.29 & 0.48 \\
\hline Neutrophils \% & $1 \pm 0.3$ & $53 \pm 19$ & 0.11 & $1 \pm 0.8$ & $53 \pm 18$ & 0.07 & 0.72 \\
\hline
\end{tabular}

Values are given as mean \pm SEM. Bronchoalveolar lavage was performed before ischaemia (baseline) and after 90 min of reperfusion. $*$ : pvalues for within treatment group comparisons (baseline versus reperfusion); ${ }^{+}$: p-values for between treatment group comparisons (control versus surfactant). 

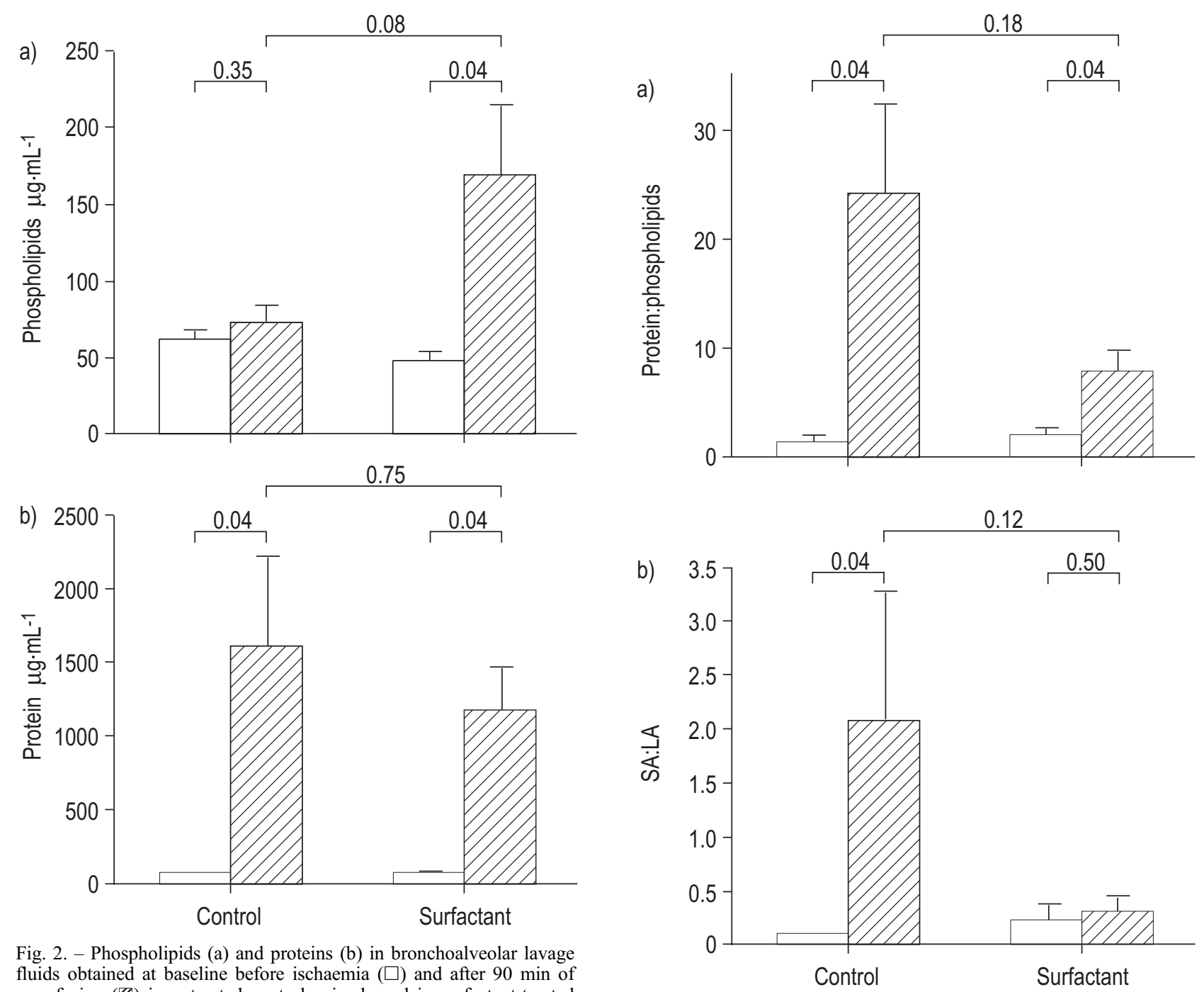

Fig. 2. - Phospholipids (a) and proteins (b) in bronchoalveolar lavage fluids obtained at baseline before ischaemia $(\square)$ and after $90 \mathrm{~min}$ of reperfusion $(\mathbb{Z})$ in untreated control animals and in surfactant-treated
animals. Values are given as mean \pm SEM and exact p-values are shown.

baseline (fig. 4b). After reperfusion, minimum surface tension increased in the control group $(\mathrm{p}=0.23)$ but was unchanged in BALF from surfactant-treated animals $(\mathrm{p}=$ 0.69 ) resulting in a significant difference of $\gamma$ min between the two study groups $(\mathrm{p}=0.01)$.

Maximum survival in control animals was $270 \mathrm{~min}$, whereas surfactant-treated animals survived at least 360 min. Animals with better survival had better surfactant function analysed after reperfusion. Adsorption rate, yads, was $<25 \mathrm{mN} \cdot \mathrm{m}^{-1}$ in all five surfactant-treated animals, while only one animal in the control group had a rads of $<25 \mathrm{mN} \cdot \mathrm{m}^{-1}$. In addition, $\gamma \mathrm{min}$ was $<2 \mathrm{mN} \cdot \mathrm{m}^{-1}$ in all surfactant-treated animals whereas only two out of five control animals had such low $\gamma$ min values.

\section{Discussion}

Reperfusion injury is characterized by a disturbance of the capillary-endothelial barrier with leakage of plasma proteins into the alveoli. In this study in pig lungs, ischaemia-reperfusion injury resulted in severe exudation of proteins into the alveoli with increased numbers of neutrophils. Surface activity of surfactant recovered from BALF after

Fig. 3. - The protein to phospholipids ratio (a) and small surfactant aggregates (SA) to large surfactant aggregates (LA) ratio (b) in bronchoalveolar lavage fluids obtained at baseline before ischaemia $(\square)$ and after $90 \mathrm{~min}$ of reperfusion $(\mathbb{Z})$ in untreated control animals and in surfactant-treated animals. Values are given as mean \pm SEM and exact $p$ values are shown.

reperfusion was markedly impaired in untreated animals, probably as a result of surfactant inhibition by exuded proteins. Plasma proteins like albumin, fibrinogen, and haemoglobin are well known inhibitors of surfactant function [9-11]. In contrast to control animals, surface activity in surfactant-treated animals was preserved, although proteins in BALF were present to the same extent. In particular, the total amount of proteins that co-pelleted during the isolation procedure of surfactant did not differ between the control and surfactant-treated animals. Therefore, other mechanisms may account for the impaired surfactant function after reperfusion. It seems reasonable to assume that altered surfactant composition contributed to the observed differences of surfactant activity. On the one hand, it has been shown that exogenous surfactant increased the percentage of well-functioning heavy subtype surfactant while on the other hand, surfactant supplementation with elevation of phospholipids and surfactant-specific proteins might improve the surfactant 

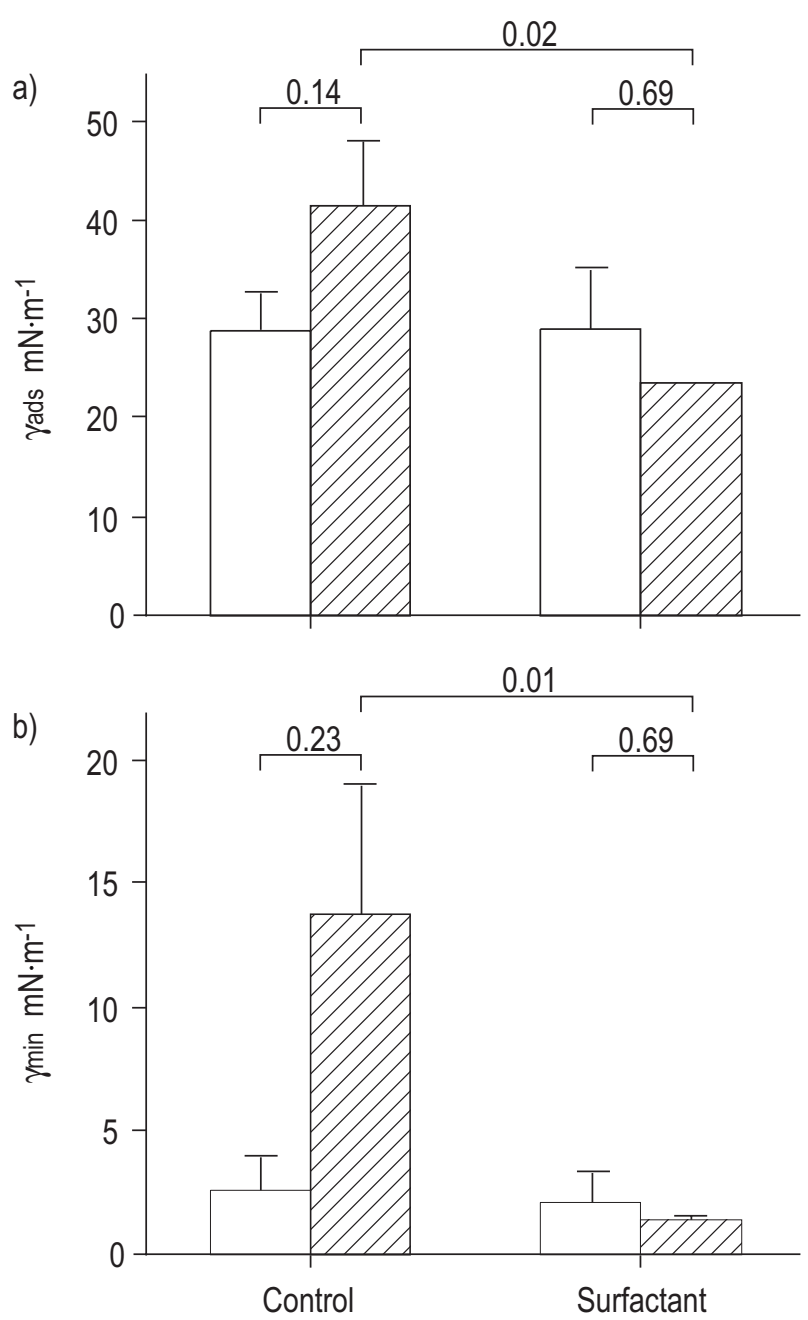

Fig. 4. - Biophysical properties of surfactant recovered from bronchoalveolar lavage fluids obtained at baseline before ischaemia $(\square)$ and after $90 \mathrm{~min}$ of reperfusion $(\mathbb{Z})$ in untreated control animals and in surfactant-treated animals. Biophysical properties are determined as surface tensions after a $10 \mathrm{~s}$ adsorption period ( $\gamma \mathrm{ads} ; \mathrm{a})$ and at minimum bubble size after 5 min of film oscillation $(\gamma \min ; b)$. Values are given as mean \pm SEM and exact $p$-values are shown.

profile, leading to enhanced surfactant activity. In addition, changes of surfactant composition after administration of exogenous surfactant might also have led to a higher resistance against surfactant inhibition by proteins. These findings that ischaemia-reperfusion injury caused surfactant dysfunction which can be preserved by exogenous surfactant treatment are in good accordance with data from the literature [4-6, 21-24, 33]. In addition, it is suggested that preservation of surfactant function might improve the outcome of ischaemia-reperfusion injury.

The experimental model of ischaemia in minipigs led to a reliable and severe reperfusion injury which invariably caused right heart failure and death within 3-4 h. Remarkably, right heart failure did not occur in surfactanttreated animals and these animals required less adrenalin to maintain cardiac output. Surprisingly, oxygenation was similar in untreated control and surfactant-treated animals. The most likely explanation for this paradoxical finding is a reduction of hypoxic pulmonary vasoconstriction in the surfactant group, since $V^{\prime} \mathrm{E}$ during reperfusion was higher in these animals compared to the control group (fig. 1). If so, the fact that the oxygenation index of the control group was not lower than the surfactant group might reflect a highly effective matching of perfusion to the reduced ventilated lung areas in the control group at the expense of increased pulmonary vasoconstriction. Another, but more speculative, explanation would be that surfactant might have some indirect effects on the regulation of pulmonary vascular tone. For instance, it has been shown that surfactant compounds can stimulate nitric oxide production of rat alveolar macrophages [34, 35], which in turn could lead to vasodilation of precapillary pulmonary arteries.

Previous studies on the effects of surfactant treatment on oxygenation in reperfusion injury have yielded conflicting results. In accordance with the present findings, Novick et al. [23] have demonstrated that treatment of transplanted dogs with instilled surfactant before reperfusion did not improve oxygenation. In contrast, ERASMUS et al. [22] have shown that surfactant treatment immediately before reperfusion improved oxygenation in experimental lung transplantation in rats. Interestingly, when surfactant was administered before lung procurement, oxygenation was significantly improved during reperfusion, suggesting that surfactant might have superior effects when given before the ischaemic damage [23]. The different effects of surfactant treatment on oxygenation in the various studies might be due to differences in species, dosing, timing, surfactant preparations and models used.

The present study has several limitations. Firstly, the number of animals per group was rather small. However, despite these low numbers, significant effects of surfactant were demonstrable. A further limitation of this study could be the fact that the control group did not undergo sham bronchoscopy with instillation of saline as a placebo dosing procedure. A sham bronchoscopy was chosen not to be carried out because saline instillation in ischaemiareperfusion injury might itself have negative effects on alveolar surfactant balance. Finally, this study provides no information on long-term outcome since it was designed to investigate the acute postoperative phase. However, it has been shown that successful early treatment of ischaemiareperfusion injury has some long lasting positive effects on pulmonary function after lung transplantation [36].

In conclusion, ischaemia-reperfusion injury in minipigs leads to deterioration of surfactant function. Exogenous surfactant treatment improves surfactant function and short-term survival. Thus, supplementation of surfactant may be an effective treatment for reperfusion injury. Further studies are needed to unravel the optimal strategies of surfactant supplementation for the prevention and treatment of reperfusion injury. Moreover, future work should concentrate on treatment modalities that protect endogenous surfactant function in reperfusion injury.

Acknowledgements. The skillful technical assistance of K. Balke, S. Knö $\beta$ and M. Schael is greatfully acknowledged. Alveofact $\AA$ was kindly provided by K. Thomae, Biberach, Germany.

\section{References}

1. Davis RDJ, Pasque MK. Pulmonary transplantation. Ann Surg 1995; 221: 14-28. 
2. Iversen S. Surgical treatment of thromboembolism-induced pulmonary hypertension. Z Kardiol 1994; 83: 193199.

3. Novick RJ, Menkis AH, McKenzie FN. New trends in lung preservation: a collective review. $J$ Heart Lung Transplant 1992; 11: 377-392.

4. Klepetko W, Lohninger A, Wisser W, et al. Pulmonary surfactant in bronchoalveolar lavage after canine lung transplantation: effect of L-carnitine application. J Thorac Cardiovasc Surg 1990; 99: 1048-1058.

5. Veldhuizen RA, Lee J, Sandler D, et al. Alterations in pulmonary surfactant composition and activity after experimental lung transplantation. Am Rev Respir Dis 1993; 148: 208-215.

6. Erasmus ME, Peterson AH, Oetomo SB, Prop J. The function of surfactant is impaired during the reimplantation response in rat lung transplants. $J$ Heart Lung Transplant 1994; 13: 791-802.

7. Andrade RS, Solien EE, Wangensteen OD, Tsai MY, Kshettry VR, Bolman RMI. Surfactant dysfunction in lung preservation. Transplantation 1995; 60: 536-541.

8. Hamm H, Kroegel C, Hohlfeld J. Surfactant: a review of its functions and relevance in adult respiratory disorders. Respir Med 1996; 90: 251-270.

9. Seeger W, Stohr G, Wolf HRD, Neuhof H. Alteration of surfactant function due to protein leakage: special interaction with fibrin monomer. $J$ Appl Physiol 1985; 58: 326-338.

10. Fuchimukai T, Fujiwara T, Takahashi A, Enhorning G. Artificial pulmonary surfactant inhibited by proteins. $J$ Appl Physiol 1987; 62: 429-437.

11. Seeger W, Grube C, Günther A, Schmidt R. Surfactant inhibition by plasma proteins: differential sensitivity of various surfactant preparations. Eur Respir J 1993; 6: 971-977.

12. Bredenberg CE, Paskanik AM, Nieman GF. High surface tension pulmonary oedema. J Surg Res 1983; 34: 515523.

13. Kobayashi T, Nitta K, Ganzuka M, Inui S, Grossmann G, Robertson B. Inactivation of exogenous surfactant by pulmonary oedema fluid. Pediatr Res 1991; 29: 353-356.

14. Holm BA, Kelcher L, Liu M, Sokolowski J, Enhorning G. Inhibition of pulmonary surfactant function by phospholipases. J Appl Physiol 1991; 71: 317-321.

15. Pison U, Tam EK, Caughey GH, Hawgood S. Proteolytic inactivation of dog lung surfactant-associated proteins by neutrophil elastase. Biochim Biophys Acta 1989; 992: 251-257.

16. Lewis RW, Harwood JL, Tetley TD, Harris E, Richards RJ. Degradation of human and rat surfactant apoprotein by neutrophil elastase and cathepsin G. Biochem Soc Trans 1993; 21: 206S.

17. Gregory TJ, Longmore WJ, Moxley MA, et al. Surfactant chemical composition and biophysical activity in acute respiratory distress syndrome. J Clin Invest 1991; 88: 1976-1981.

18. Günther A, Siebert C, Schmidt R, et al. Surfactant alterations in severe pneumonia, acute respiratory distress syndrome, and cardiogenic lung oedema. Am J Respir Crit Care Med 1996; 153: 176-184.

19. Walmrath D, Günther A, Ghofrani HA, et al. Bronchoscopic surfactant administration in patients with severe adult respiratory distress syndrome and sepsis. $\mathrm{Am} \mathrm{J}$ Respir Crit Care Med 1996; 154: 57-62.

20. Gregory TJ, Steinberg KP, Spragg R, et al. Bovine surfactant therapy for patients with acute respiratory distress syndrome. Am J Respir Crit Care Med 1997; 155: 1309-1315.

21. Novick RJ, Veldhuizen RAW, Possmayer F, Lee J, Sandler D, Lewis JF. Exogenous surfactant therapy in thirtyeight hour lung graft preservation for transplantation. $J$ Thorac Cardiovasc Surg 1994; 108: 259-268.

22. Erasmus ME, Petersen AH, Hofstede G, Haagsman HP, Bambang-Oetomo S, Prop J. Surfactant treatment before reperfusion improves the immediate function of lung transplants in rats. Am J Respir Crit Care Med 1996; 153: 665-670.

23. Novick RJ, MacDonald J, Veldhuizen RAW, et al. Evaluation of surfactant treatment strategies after prolonged graft storage in lung transplantation. Am J Respir Crit Care Med 1996; 154: 98-104.

24. Hausen B, Rohde R, Hewitt CW, et al. Exogenous surfactant treatment before and after sixteen hours of ischemia in experimental lung transplantation. $J$ Thorac Cardiovasc Surg 1997; 113: 1050-1058.

25. Strüber M, Cremer J, Harringer W, Hirt SW, CostardJackle A, Haverich A. Nebulized synthetic surfactant in reperfusion injury after single lung transplantation. $J$ Thorac Cardiovasc Surg 1995; 110: 563-564.

26. Institute of Laboratory Animal Resources National Institutes of Health. Guide for the Care and Use of Laboratory Animals. Washington DC, National Academy Press, 1996.

27. Haverich A, Aziz S, Scott WC, Jamieson SW, Shumway NE. Improved lung preservation using Euro-Collins solution for flush-perfusion. Thorac Cardiovasc Surg 1986; 34: $368-376$.

28. Lowry OH, Rosebrough NJ, Farr AL, Randall RJ. Protein measurement with the folin phenol reagent. J Biol Chem 1951; 193: 265-275.

29. Barlett GR. Phosphorus assay in column chromatography. J Biol Chem 1959; 234: 466-468.

30. Bligh EG, Dyer WJ. A rapid method of total lipid extraction and purification. Can J Biochem Physiol 1959; 37: 911-917.

31. Enhorning G. Pulsating bubble technique for evaluating pulmonary surfactant. J Appl Physiol 1977; 43: 198-203.

32. Rosner BA. Fundamentals in Biostatistics. 4th Edn. Belmont, CA, Duxberry Press, 1995.

33. Buchanan SA, Mauncy MC, Parekh VI, et al. Intratracheal surfactant administration preserves airway compliance during lung reperfusion. Ann Thorac Surg 1996; 62: 1617-1621.

34. Blau H, Rikhs S, Van Iwaarden JF, McCormack FX, Kalina M. Nitric oxide production by rat alveolar macrophages can be modulated in vitro by surfactant protein A. Am J Physiol 1997; 272: L1198-L1204.

35. Miles PR, Bowmann L, Rengasamy A, Huffman L. Alveolar type II cell cNOS activity and ATP levels are increased by lung surfactant or DPPC vesicles. Am J Physiol 1997; 273: L339-L346.

36. Bacha EA, Herve P, Murakami S, et al. Lasting beneficial effect of short term inhaled nitric oxide on graft function after lung transplantation. J Thorac Cardiovasc Surg 1996; 112: 590-598. 